\title{
Constitution of KPI System for Third Party Logistics Enterprises
}

\author{
Xi Qin, Wei Xing \\ Hunan Vocational College of Modern Logistics, Changsha, 410131, China \\ 760933676@qq.com
}

Keywords: Third-party logistics, KPI, Key performance indicator, Performance evaluation, Critical success factor.

\begin{abstract}
In view of the rapid development of the third-party logistics industry, but not format scientific and rational evaluation system status quo, this paper based on the key success factor method to start research. First, the paper studies the composition of the third-party logistics enterprises performance indicators, including finance, customer, business process, technological innovation and staff growth. Then, it studies the key success factors of the third-party logistics enterprises, decomposes through the strategic goal, and then coordinate the performance evaluation objectives; Finally, according to the key success factor method to sort out the key performance indicators, the formation of KPI system. The research results of this paper have an important role in improving the performance of logistics enterprises, accelerating the development of logistics industry, promoting the rationalization of industrial structure and improving the international competitiveness of logistics enterprises.
\end{abstract}

\section{Introduction}

Third-party logistics refers to the production and operation of enterprises to focus on doing the main business, the original logistics activities belongs to their own contract to the professional logistics services business, while information systems and logistics enterprises maintain close contact to achieve the logistics full management and control a kind of logistics operation and management[1]. Third-party logistics is conducive to business focus on the main business, reduce inventory, reduce investment, speed up capital turnover, flexible use of new technologies to improve customer service levels, reduce logistics costs and enhance corporate image. Third-party logistics enterprises have the following characteristics: First, the independent business entity, not the producer, not the end user, but no ownership of goods outside the enterprise. Second, the customer logistics system provide full-service, different from the traditional transport and warehousing business, pay more attention to integrated logistics functions, including information services and financial settlement work, focusing on the overall operational efficiency. Third, the customer is a close combination of strategic partnership, usually have long-term cooperation contract, through the contract to regulate and clear their rights and obligations. Fourth, based on the development of information technology on the basis of relying on information technology to achieve rapid data transmission, improve the level of automation of logistics operations to achieve the integration of logistics services.

KPI (Key Performance Indicator) is a kind of goal-based quantitative management index which measures the performance in the process. It is the basis of enterprise performance management to decompose the enterprise strategic goal into operational work[2]. KPI is strategic guide, reflecting the quantification and highlight the main contradictory management ideas. The purpose of the KPI performance appraisal is to translate the strategic objectives of the enterprise into internal processes and activities, and establish a kind of mechanism to continuously enhance the core competitiveness of enterprises and continue to achieve high efficiency. Therefore, KPI is both a tool for performance appraisal and method, but also a strategic performance management ideas. KPI performance assessment has the following characteristics: the strategic objectives of the enterprise 
decomposition, and with the evolution of corporate strategy was amended; effective reflection of key business performance factors and changes in the measurement parameters; performance measures can affect the part of the measure; The reflection of operational action is not a reflection of all operational processes.

For building the third-party logistics enterprises to KPI system, so that managers will focus on the performance of the largest driving business behavior, the timely diagnosis of production and management problems to improve the performance level to improve measures, and then through the decomposition of KPI indicators to ensure that employees complete the most important and core of the work, improve business efficiency and customer satisfaction.

\section{Constitution on Performance Indicators of Third Party Logistics Enterprises}

Establish scientific and effective enterprise performance evaluation system, select the key factors affecting the success of the enterprise strategy to form systematic evaluation index system. There must be causal chain relationship between different angles, the use of this relationship, the strategic thinking of enterprises into operational tactical objectives, in order to facilitate the understanding and implementation of the staff so that all the activities of enterprises around the formation of the core competitive advantages achieve strategic objectives.

In the era of knowledge economy, enterprises face the new business environment, briefly summarized as "3C": Corporation, Customer and Competition. Must make companies, customers and competitors into the same strategy to maintain the competitive advantages. In order to adapt to the "3C" as the main features of the new environment, modern enterprises must quickly achieve "two fundamental changes". From product-centric to customer-centric, from customer-centric to profit-centric change. The most important thing is the customer-centric, people-oriented, nurturing innovation, and continuously improve business operations. Modern enterprise development should focus on the five focus is to develop customers, motivate employees, focus on innovation, strengthen operations and achieve profits. In order to effectively achieve these five objectives, the enterprise performance evaluation system from these five aspects, as shown in Fig.1.

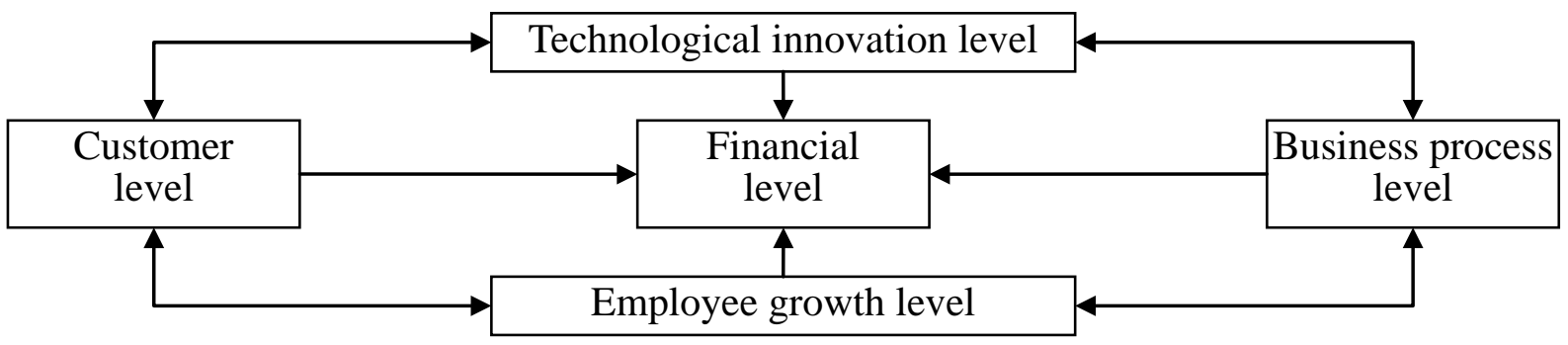

Fig. 1. Constitution on performance indicators of third party logistics enterprises

(1) Financial level. Financial indicators are of the utmost importance, and other indicators need to be implemented at the financial level and serve the financial dimension. To achieve business goals, it is necessary to make customers satisfied, customers are satisfied with the products or services provided by the enterprise, directly related to the value created by the enterprise is recognized, whether the cost of compensation, whether the profits achieve the maximize obtainment.

(2) Customer level. Logistics enterprises in the production and operation, not only in order to obtain direct financial benefits, but also consider the development and maintenance of strategic resources, that is, customers bring logistics services products market, which is the logistics company's strategic growth material basis. Evaluation at the customer level is the measure of the performance of external resource development and utilization that companies rely on for survival. Specifically, it refers to the performance of the customer's exploration development and the measurement of profitability from the customer.

(3) Business process level. The business process reflects the resources and efficiency of the internal operations. Excellent customer performance comes from the processes, decisions, and 
behaviors that occur in enterprises organization. Management needs to focus on key internal business activities that can meet customer needs, directly affecting the customer-level key indicators, and indirectly affect the financial aspects. Enterprise's excellent internal business performance comes from the core competencies of the enterprises.

(4) Technological innovation level. Through technological innovation, improve product quality, develop new products, provide new services, occupy the market and realize market value. Innovation is the key to the format the core competitiveness of enterprises, is the dominant factor in the success of enterprises. Only through continuous innovation, in order to provide customers with more and better logistics products, in order to continuously expand the market share in order to make logistics services to the information age, in order to always maintain competitive advantage.

(5) Employee growth level. Logistics enterprises in order to maintain the core competitiveness, achieve sustainable development, we must rely on every staff. Enterprises should attach great importance to the staff learning and training investment to help employees grow. Special logistics professionals in the case of shortage of enterprises should pay attention to the use of a variety of ways to establish wholesome talent reservation system, the construction of logistics personnel, give full play to the effectiveness of talent to ensure that enterprises achieve sustainable development.

\section{Critical Success Factor of Third Party Logistics Enterprises}

After establishing the structure of performance indicators, it is necessary to determine the specific targets of each index. In order to avoid the vertical contradiction between the strategic objectives and the performance indicators, the horizontal dissonance between the various departments of the enterprise needs to be decomposed. In order to ensure the realization of corporate goals under the premise of layers of decomposition, format the consistent and harmonious performance appraisal objectives. Reference to the relevant literature[3], the third-party logistics business strategic objectives after the decomposition of the performance objectives shown in Table 1.

Table 1. Performance goal of third party logistics enterprises

\begin{tabular}{|c|c|c|c|}
\hline Key party & Main demand & Critical success factor & Indicators type \\
\hline Customer & $\begin{array}{l}\text { - Timely delivery } \\
\text { - Considerate service } \\
\text { - Low cost } \\
\text { - Value added service } \\
\text { - Personalized service }\end{array}$ & $\begin{array}{l}\text { - Accelerate the application of new } \\
\text { technologies } \\
\text { - Improve service awareness and level } \\
\text { - Provide related services } \\
\text { - Establish brand awareness and good } \\
\text { enterprise image }\end{array}$ & $\begin{array}{l}\text { - Customer class } \\
\text { - Business process } \\
\text { class } \\
\text { - Technological } \\
\text { innovation class }\end{array}$ \\
\hline Enterprise & $\begin{array}{l}\text { - Market share } \\
\text { - Business growth rate } \\
\text { - Economic results } \\
\text { - Risk-prevention } \\
\text { - Customer satisfaction } \\
\text { - Reputation and social } \\
\text { image }\end{array}$ & $\begin{array}{l}\text { - Increase marketing efforts } \\
\text { - Control costs } \\
\text { - Strengthen risk awareness } \\
\text { - Improve service awareness and level } \\
\text { - Improve the level of information }\end{array}$ & $\begin{array}{l}\text { - Financial class } \\
\text { - Business process } \\
\text { class } \\
\text { - Employee growth } \\
\text { class } \\
\text { - Technological } \\
\text { innovation class }\end{array}$ \\
\hline Staff & $\begin{array}{l}\text { - Career development } \\
\text { - Management fairness } \\
\text { - Learning opportunity } \\
\text { - Spiritual needs } \\
\text { - Material demand } \\
\text { - Salary and welfare }\end{array}$ & $\begin{array}{l}\text { - Reasonable employment mechanism } \\
\text { - Standardize management processes } \\
\text { and systems } \\
\text { - Increase training and practice } \\
\text { opportunities } \\
\text { - Establish smooth communication } \\
\text { channels } \\
\text { - Reasonable salary incentive system }\end{array}$ & $\begin{array}{l}\text { - Business process } \\
\text { class } \\
\text { - Employee growth } \\
\text { class } \\
\text { - Financial class }\end{array}$ \\
\hline
\end{tabular}


KPI System of Third Party Logistics Enterprises

Third-party logistics as the production and operation of enterprises provide contractual way to provide professional logistics services business, the process of key control points covering time, cost, risk, results and other four aspects.

The specific principles of performance indicators are: understandable, controllable, enforceable, measurable, low-cost access, consistent with overall strategic objectives, consistent with overall performance indicators. Test the performance indicators, which do not match need to modify or eliminate. After testing and finishing, the key performance indicators of the third-party logistics enterprises are obtained, and the key performance indicators are collated according to the requirements of the key success factor method to form the KPI system. Reference to the relevant literature[4-6], finishing the key performance indicators are as follows:

(1) Financial level, including five indicators:

- Sales revenue (evaluation of business scale)

- Growth of interest rate (evaluation of the main business profitability development)

- Return on equity (measure the efficiency of the enterprise's own capital)

- Asset-liability ratio (measure the level of enterprise debt and risk)

- Operating cost reduction rate (ratio to previous cost level)

(2) Customer level, including five indicators:

- Customer satisfaction rate (satisfaction with the provision of logistics services)

- Customer retention rate (maintain the business relationship with the old customer ratio)

- Customer acquisition rate (percentage of new customers or business)

- Market share (proportion of business in the logistics service market)

- Customer Profitability (level of profit from customer)

(3) Business process level, including five indicators:

- Plan completion rate (completion of synthesis response plan)

- Cargo damage compensation rate (damage to the enterprise bring the loss)

- Accurate delivery rate (consistent with customer specified goods)

- Customer demand satisfaction rate (logistics demand in a timely manner to meet the ratio)

- Production capacity utilization rate(actual business volume and machine equipment can provide the ratio of business)

(4) Technological innovation level, including five indicators:

- Information level (now the degree of application of information technology)

- R \& D investment (new technology and new product R \& D investment level)

- Return on investment in new logistics products (ratio of input to profit)

- New product income ratio (income ratio to original logistics product)

- Cost reduction rate (using new technology to reduce logistics costs)

(5) Employee growth level, including five indicators:

- Employee knowledge level (available level of staff assessment)

- Employee turnover rate (as percentage of employee turnover)

- Employee productivity (average income or value created by the staff)

- Employee training (measured by training frequency and training costs)

- Employee promotion (referring to the staff of the technical upgrade or job promotion, etc.)

\section{Conclusion}

Logistics performance management is meeting the requirements of customer service under the premise of the entire process of logistics operations on the logistics results and the effectiveness of the formation and evaluation of the planning, organization, coordination and control. Logistics performance evaluation is the basis for the enterprise to carry out scientific comprehensive performance management, and it is an effective part to promote the establishment of incentive and restraint mechanism. With the increasing importance of performance management in enterprises, KPI key performance indicators have been paid more and more attention by managers at all levels as a practical and effective tool in performance management process. The research results of this 
paper play an important role in improving the performance of logistics enterprises, accelerating the development of logistics industry, promoting the rationalization of industrial structure and improving the international competitiveness of logistics enterprises. In the actual application process, KPI cannot be considered as simple decomposition process, which should ensure that from the way of thinking and cognitive point of view to grasp the correct direction, and achieve the ultimate effect of KPI.

\section{References}

[1] L. Miao, W. J. Pan, "Empirical Study on Third - party Logistics Ogistics Enterprise Performance Based on the Customer Service Level," Journal of Harbin University of Commerce (Social Science Edition), vol. 33, no. 1, pp. 40-49, 2017.

[2] Times brilliance, "What is the function of KPI index?," http://www.hztbc.com/news/news_42785.html, 2017-10-10.

[3] Baidu Wenku, "Analysis of key success factors in logistics industry," https://wenku.baidu.com/view/8361cb3eb307e87101f696b9.html, 2017-10-10.

[4] J. Liu, "Study on Performance Evaluation of the Third-party Logistics Enterprise Based on Balanced Scorecard," Logistics Sci-Tech, vol. 41, no. 4, pp. 56-58, 2016.

[5] X. Z. Wang, S. J. Wu, Y. B. Yang, "Construction and application of performance evaluation system of third party logistics enterprises," Finance and Accounting Monthly, vol. 37, no. 18, pp. 81-85, 2016.

[6] X. Jia, "Establishment of Customer Relationship Management Performance Evaluation System of TPL Enterprises Based on BSC," Logistics Technology, vol. 34, no. 9, pp. 61-64, 2015. 